\title{
Michał Leciak
}

\section{Prawnokarne aspekty nowej ustawy o ochronie informacji niejawnych}

\section{Wprowadzenie}

Ustawą z 5 sierpnia 2010 r. o ochronie informacji niejawnych ${ }^{1}$ dokonano w krajowym porządku normatywnym znaczącego przemodelowania systemu ochrony informacji niejawnych. Zmiany te wchodzą w życie z 2 stycznia 2011 r. Ich przeprowadzenie argumentuje się przede wszystkim przestarzałym i niefunkcjonalnym charakterem dotychczas obowiązujących regulacji ustawy z 22 stycznia 1999 r. o ochronie informacji niejawnych ${ }^{2}$, a zarazem potrzebą dostosowania krajowych rozwiązań normatywnych do standardów NATO oraz Unii Europejskiej ${ }^{3}$.

Jednym $z$ istotnych założeń nowej ustawy jest zastąpienie funkcjonujących dotychczas definicji legalnych tajemnicy państwowej i tajemnicy służbowej zbiorczym pojęciem „informacja niejawna”, której stopień ochrony został uzależniony od charakteru nadanej jej klauzuli tajności („ściśle tajne”, „tajne”, „poufne”, „zastrzeżone”). Uzasadnienie takiego rozwiązania wiąże się z krytyką istniejącego dwustopniowego systemu definiowania informacji niejawnych, a także, zdaniem ustawodawcy, nierespektowaniem w praktyce

1 Dz.U. z 2010 r. Nr 182, poz. 1228.

2 Dz.U. z 1999 r. Nr 11, poz. 95 ze zm.

3 Zob. Uzasadnienie rządowego projektu ustawy o ochronie informacji niejawnych oraz o zmianie niektórych ustaw z 16 lutego 2010 r., druk nr 2791 , s. $1-2$. 
wykazów zawartych w załączniku do ustawy z 1999 r. ${ }^{4} \mathrm{Z}$ racji tego, że wiele obowiązujących aktów prawnych posługiwało się terminami „tajemnica państwowa” oraz „tajemnica służbowa”, konieczna stała się nowelizacja ponad 100 aktów, polegająca właśnie na zastąpieniu tych dwu terminów jednym - „informacja niejawna”. Tego typu zmiany musiały również objąć instrumentarium prawnokarne, co ustawodawca uwzględnił, wprowadzając powołaną ustawą nowelizację art. $265 \S 1$ k.k. i $266 \S 2$ k.k. (art. 107 ustawy). Koncentruje się ona na modyfikacji ustawowych znamion przestępstw ujętych w tych przepisach, odnoszących się do przedmiotu czynności wykonawczej, przez zastąpienie użytych w nich terminów „tajemnica państwowa” oraz „tajemnica służbowa” terminem „informacja niejawna” o klauzuli „tajne” lub „ściśle tajne” (art. 265 § 1 k.k.) oraz „informacja niejawna” o klauzuli „zastrzeżone” lub „poufne” (art. $266 \S 2$ k.k.). Może się wydawać, że to jedyne następstwa uchwalenia nowej ustawy o ochronie informacji niejawnych w płaszczyźnie prawnokarnej. Dokonane modyfikacje kodeksowe, pomimo ich pozornej powierzchowności, implikują jednak istotne zmiany co do sposobu wykładni znamion przestępstw stypizowanych w art. $265 \S 1$ k.k. i art. $266 \S 2$ k.k. O ich dokonaniu można wszak mówić po nowelizacji jedynie wtedy, gdy ujawniono lub wykorzystano informację, którą wcześniej opatrzono klauzulą tajności. Uznając ponadto za trafne dominujące w literaturze przekonanie ${ }^{5}$, że rekonstrukcja merytorycznych norm zakazu w obrębie przestępstw $\mathrm{z}$ art. $265 \S 1$ k.k. i art. $266 \S 2$ k.k. jest możliwa dopiero po sięgnięciu do konstrukcji pozakodeksowych, w tym przepisów ustawy o ochronie informacji niejawnych, okazuje się, iż uchwalenie nowej ustawy regulującej wskazaną materię normatywną wpływa istotnie

\footnotetext{
4 Ibidem, s. 3.

5 Zob. m.in.: W. Wróbel, Prawnokarna ochrona tajemnicy państwowej, Czasopismo Prawa Karnego i Nauk Penalnych 2000, nr 1, s. 124 i n.; A. Marek, Kodeks karny. Komentarz, Warszawa 2006, s. 477-480; M. Leciak, Tajemnica państwowa i jej ochrona $w$ prawie karnym materialnym i procesie karnym, Toruń 2009, s. 116 i n.; idem, Glosa do uchwały Sądu Najwyższego z dnia 26 marca 2009 r., I KZP 35/08, Prokuratura i Prawo 2009, nr 9, s. 160 i n.; J. Piórkowska-Flieger [w:] Kodeks karny. Komentarz, red. T. Bojarski, Warszawa 2008, s. 542 i n.
} 
na interpretację także innych znamion wspomnianych przestępstw kodeksowych. Ocena nowelizacji materii prawnokarnej wymaga więc wstępnie analizy dokonanych zmian na gruncie ustawy o ochronie informacji niejawnych.

\section{Normatywny charakter informacji niejawnych}

Jak wcześniej wskazano, nowa ustawa o ochronie informacji niejawnych zakłada rezygnację $z$ pojęć „tajemnica państwowa” oraz „tajemnica służbowa” w polskim porządku normatywnym na rzecz pojęć „informacja niejawna” o klauzuli „ściśle tajne” oraz „informacja niejawna” o klauzuli „tajne” (które zastąpiły tajemnicę państwową), a także „informacja niejawna” o klauzuli „zastrzeżone” oraz „informacja niejawna” o klauzuli „poufne” (które zastąpiły tajemnicę służbową). Rekonstrukcja tych pojęć wymaga natomiast wcześniejszej interpretacji dwóch elementów normatywnych.

Pierwszy $z$ nich został określony w art. 1 ust. 1 ustawy, gdzie wyjaśniono pojęcie „informacje niejawne”. W ujęciu tego przepisu za informacje niejawne uznano takie, „których nieuprawnione ujawnienie spowodowałoby lub mogłoby spowodować szkody dla Rzeczypospolitej Polskiej albo byłoby z punktu widzenia jej interesów niekorzystne, także w trakcie ich opracowywania oraz niezależnie od formy i sposobu ich wyrażania”.

Drugą podstawę normatywną niezbędną do odtworzenia pojęcia informacji niejawnej o określonej klauzuli tajności stanowi art. 5 ustawy. Zgodnie $z$ art. 5 ust. 1,

Informacjom niejawnym nadaje się klauzulę „ściśle tajne”, jeżeli ich nieuprawnione ujawnienie spowoduje wyjątkowo poważną szkodę dla Rzeczypospolitej Polskiej przez to, że:

1) zagrozi niepodległości, suwerenności lub integralności terytorialnej Rzeczypospolitej Polskiej;

2) zagrozi bezpieczeństwu wewnętrznemu lub porządkowi konstytucyjnemu Rzeczypospolitej Polskiej;

3) zagrozi sojuszom lub pozycji międzynarodowej Rzeczypospolitej Polskiej; 
4) osłabi gotowość obronną Rzeczypospolitej Polskiej;

5) doprowadzi lub może doprowadzić do identyfikacji funkcjonariuszy, żołnierzy lub pracowników służb odpowiedzialnych za realizację zadań wywiadu lub kontrwywiadu, którzy wykonują czynności operacyjno-rozpoznawcze, jeżeli zagrozi to bezpieczeństwu wykonywanych czynności lub może doprowadzić do identyfikacji osób udzielających im pomocy w tym zakresie;

6) zagrozi lub może zagrozić życiu lub zdrowiu funkcjonariuszy, żołnierzy lub pracowników, którzy wykonują czynności operacyjno-rozpoznawcze, lub osób udzielających im pomocy w tym zakresie;

7) zagrozi lub może zagrozić życiu lub zdrowiu świadków koronnych lub osób dla nich najbliższych albo świadków, o których mowa w art. 184 ustawy z dnia 6 czerwca 1997 r. - Kodeks postępowania karnego (Dz.U. Nr 89, poz. 555 ze zm.), lub osób dla nich najbliższych.

Ponadto w ujęciu art. 5 ust. 2 ustawy

Informacjom niejawnym nadaje się klauzulę „tajne”, jeżeli ich nieuprawnione ujawnienie spowoduje poważną szkodę dla Rzeczypospolitej Polskiej przez to, że:

1) uniemożliwi realizację zadań związanych z ochroną suwerenności lub porządku konstytucyjnego Rzeczypospolitej Polskiej;

2) pogorszy stosunki Rzeczypospolitej Polskiej z innymi państwami lub organizacjami międzynarodowymi;

3) zakłóci przygotowania obronne państwa lub funkcjonowanie Sił Zbrojnych Rzeczypospolitej Polskiej;

4) utrudni wykonywanie czynności operacyjno-rozpoznawczych prowadzonych w celu zapewnienia bezpieczeństwa państwa lub ścigania sprawców zbrodni przez służby lub instytucje do tego uprawnione;

5) w istotny sposób zakłóci funkcjonowanie organów ścigania i wymiaru sprawiedliwości;

6) przyniesie stratę znacznych rozmiarów w interesach ekonomicznych Rzeczypospolitej Polskiej”. 
Klauzulę „poufne” nadaje się natomiast informacjom niejawnym,

jeżeli ich nieuprawnione ujawnienie spowoduje szkodę dla Rzeczypospolitej Polskiej przez to, że:

1) utrudni prowadzenie bieżącej polityki zagranicznej Rzeczypospolitej Polskiej;

2) utrudni realizację przedsięwzięć obronnych lub negatywnie wpłynie na zdolność bojową Sił Zbrojnych Rzeczypospolitej Polskiej;

3) zakłóci porządek publiczny lub zagrozi bezpieczeństwu obywateli;

4) utrudni wykonywanie zadań służbom lub instytucjom odpowiedzialnym za ochronę bezpieczeństwa lub podstawowych interesów Rzeczypospolitej Polskiej;

5) utrudni wykonywanie zadań służbom lub instytucjom odpowiedzialnym za ochronę porządku publicznego, bezpieczeństwa obywateli lub ściganie sprawców przestępstw i przestępstw skarbowych oraz organom wymiaru sprawiedliwości;

6) zagrozi stabilności systemu finansowego Rzeczypospolitej Polskiej;

7) wpłynie niekorzystnie na funkcjonowanie gospodarki narodowej”.

Z kolei klauzulę „zastrzeżone” nadaje się informacjom niejawnym,

jeżeli nie nadano im wyższej klauzuli tajności, a ich nieuprawnione ujawnienie może mieć szkodliwy wpływ na wykonywanie przez organy władzy publicznej lub inne jednostki organizacyjne zadań w zakresie obrony narodowej, polityki zagranicznej, bezpieczeństwa publicznego, przestrzegania praw i wolności obywateli, wymiaru sprawiedliwości albo interesów ekonomicznych Rzeczypospolitej Polskiej.

Analiza dwóch określonych wyżej elementów normatywnych (art. 1 ust. 1 i art. 5 ustawy), współtworzących omawiane definicje informacji niejawnych, budzi zastrzeżenia. Wydaje się, że brzmiące lakonicznie i niezrozumiale założenia ustawodawcy w tym zakresie wyartykułowane w uzasadnieniu do projektu nowej ustawy nie będą mogły w praktyce zostać zrealizowane. Wskazano w nim wyraźnie, że

Istotą projektu nowej ustawy o ochronie informacji niejawnych jest takie unormowanie systemu ich ochrony, aby był on maksymalnie efektywny 
zarówno w sferze krajowej, jak i zagranicznej, przy jednoczesnej prostocie i elastyczności funkcjonowania, ale bez uszczerbku dla bezpieczeństwa informacji niejawnych. Podstawowym zatem celem stało się uproszczenie istniejącego systemu i jego aktualizacja. Dotychczasowe rozwiązania powodują bowiem z jednej strony wymóg nadawania klauzul tajności olbrzymiej liczbie informacji, w wielu przypadkach nie wymagających ochrony oraz notoryczne zawyżanie klauzul bez żadnego racjonalnego uzasadnienia, z tego tylko powodu, że dana informacja, w pewnych okolicznościach „może” stanowić informację niejawną [...]. Konieczność opracowania nowego aktu prawnego wynika przede wszystkim z potrzeb praktyki, ponieważ stosowanie obowiązującej ustawy sprawia trudności, w tym rodzi wątpliwości interpretacyjne, oraz z potrzeby poprawy efektywności systemu ochrony informacji niejawnych [...]. Regulacja wyznacza granicę między dostępem do informacji publicznej a nakazem ochrony informacji i obowiązkiem zachowania tajemnicy. Granica ta, w konsekwencji zmian w definicjach poszczególnych klauzul tajności, zostaje przesunięta powiększając zakres informacji publicznej. Regulacja może wpłynąć na zwiększenie jawności życia publicznego i ułatwić dostęp do informacji publicznej. Tym samym, regulacja poszerza sferę wolności i praw jednostek, zmniejszając ograniczenia prawa do informacji o działalności organów władzy publicznej ${ }^{6}$.

Tymczasem przyjęta przez ustawodawcę koncepcja ochrony informacji niejawnych jest $\mathrm{w}$ istotnym stopniu ogólna i nieprecyzyjna. Wskazane wyżej definicje legalne są na tyle niejasne i ocenne, że ich jednolita interpretacja może okazać się w praktyce niemożliwa ${ }^{7}$. Stwierdzenie to dotyczy zarówno elementu $z$ art. 1 ust. 1 ustawy, jak i definicji określonych w art. 5 ustawy. Po pierwsze należy zauważyć, że ustawodawca różnicuje możliwości nadawania informacjom niejawnym określonych klauzul tajności w zależności od charakteru szkody, która zostanie spowodowana w razie ich nieuprawnionego ujawnienia. Przyjęty w tym zakresie „katalog szkód”

6 Zob. Uzasadnienie, s. 2, 17 i 23.

7 Zob. Opinia Helsińskiej Fundacji Praw Człowieka o projekcie ustawy o ochronie informacji niejawnych (wersja robocza z 15 lipca 2009 r.), Warszawa 26.08.2009 r., s. 2-3. 
wydaje się zupełnie niejasny i niedookreślony. Zdecydowano bowiem, że rodzaj nadanej klauzuli tajności musi pozostawać w ścisłej relacji z jedną z czterech kategorii szkód: „wyjątkowa poważna szkoda dla Rzeczypospolitej Polskiej” (klauzula „ściśle tajne”), „poważna szkoda dla Rzeczypospolitej Polskiej” (klauzula „tajne”), „szkoda dla Rzeczypospolitej Polskiej” (klauzula „poufne”) i „szkodliwy wpływ na wykonywanie przez organy władzy publicznej lub inne jednostki organizacyjne określonych zadañ” (klauzula „zastrzeżone”). Nie trzeba chyba w świetle takiej redakcji powyższych elementów ustawowych przekonywać, że tego typu prognozowanie wystąpienia konkretnej szkody może mieć charakter stricte abstrakcyjny, a tym samym prowadzić do nadinterpretacji i niejednolitego stosowania prawa. Stwierdzenie to okazuje się tym bardziej uzasadnione, gdy zwróci się uwagę na pozostałe elementy definicji informacji niejawnych $z$ art. 5 ustawy. Wyjaśniono w nich, na czym jedna z czterech wymienionych kategorii szkód dla Rzeczypospolitej Polskiej ma faktycznie polegać. Sformułowanie wykazu tego typu szkód ma jednak ponownie charakter bardzo nieprecyzyjny, co m.in. sprawia, że kryteria $z$ katalogów przewidzianych dla poszczególnych klauzul mogą się pokrywać. Dla przykładu, słusznie zauważa się, że uniemożliwienie realizacji zadań związanych z ochroną suwerenności (art. 5 ust. 2 ustawy - warunek nadania klauzuli „tajne”) wydaje się dalej idące niż stworzenie zagrożenia dla suwerenności (art. 5 ust. 1 ustawy - warunek nadania klauzuli „ściśle tajne”), wszak stworzenie takiego zagrożenia nie musi wcale uniemożliwiać realizacji zadań związanych $z$ ochroną suwerenności ${ }^{8}$. Następstwa przedstawionej oceny mogą znowu wiązać się z możliwością nadinterpretacji i przykładowo różnych decyzji urzędnika co do tych samych kategorii informacji. Takie rozwiązanie wydaje się niekorzystne tak z punktu widzenia ochrony praw i wolności jednostki, jak i interesów samego państwa, skoro stwarza realną możliwość np. nadawania informacjom niższych niż przewidziane klauzul tajności.

8 Zob. Opinia TP S.A. w sprawie projektu ustawy o ochronie informacji niejawnych, Warszawa 21.08.2009 r., s. 3. 
Wypada ponadto wyznaczyć relacje, które zachodzą pomiędzy definicjami legalnymi $z$ art. 5 ustawy a elementem $z$ art. 1 ust. 1 ustawy. Prima vista mogłoby się wydawać, że treść art. 1 ust. 1 jest na tyle ogólna, że tego typu regulacja jest po prostu niepotrzebna, w szczególności zważywszy na fakt, iż jej doprecyzowanie nastąpiło w art. 5 ustawy. Problem okazuje się jednak bardziej złożony, faktycznie bowiem klauzule normatywne $z$ art. 1 ust. 1 i art. 5 ustawy nie korespondują ze sobą. Po pierwsze art. 5 ustawy uznaje za informacje niejawne wyłącznie te wiadomości, których „nieuprawnione ujawnienie spowoduje" jedną $z$ ujętych w tym przepisie szkód. Definicja określona $\mathrm{w}$ art. 1 ust. 1 wskazuje natomiast także na jedynie potencjalne niebezpieczeństwo powstania szkody („mogłoby spowodować szkody dla Rzeczypospolitej Polskiej”). Poza tym w art. 1 ust. 1 eksponuje się potrzebę ochrony wyłącznie interesów Rzeczypospolitej Polskiej, podczas gdy kryteria klasyfikowania informacji określone w art. 5 wydają się szersze. Pojawia się wreszcie w tle tych relacji pytanie, o faktyczne rozumienie przez ustawodawcę pojęcia informacji niejawnej. Chodzi mianowicie o ustalenie, czy kryteria jej ochrony są ściśle zależne od faktu nadania jej określonej klauzuli tajności. Okazuje się bowiem, że w drodze nowelizacji ustawodawca wprowadził do krajowego porządku normatywnego zarówno te regulacje, które tworzą instrumenty ochrony wyłącznie informacji niejawnych zaopatrzonych w gryf tajności, jak i te, dla których okoliczność ta ma charakter wręcz akcydentalny.

Warto w tym kontekście zwrócić uwagę na dość istotny na gruncie ustawy z 1999 r. problem zasięgu zastosowania legalnych definicji tajemnicy państwowej oraz tajemnicy służbowej. Ich wyjaśnienie w art. 2 pkt 1 i 2 ustawy z 1999 r. ustawodawca poprzedził zwrotem „w rozumieniu ustawy”, co skłaniało niektórych autorów do postulowania ich wąskiej interpretacji, czyli ograniczonej wyłącznie do ustawy o ochronie informacji niejawnych ${ }^{9}$. Tym samym uważano, że normatywne określenia tych tajemnic używane na

9 Zob. B. Kunicka-Michalska [w:] Kodeks karny. Część szczególna. Komentarz, t. III, red. A. Wąsek, Warszawa 2005, s. 499; S. Hoc, Kilka uwag dotyczacych przestępstwa z art. 265 k.k., Wojskowy Przegląd Prawniczy 2003, nr 4, s. 89. 
gruncie innych ustaw, np. Kodeksu karnego, mają inny zakres znaczeniowy. Tego typu niezrozumiały pogląd przyjął zresztą Sąd Najwyższy w uzasadnieniu uchwały z 26 marca 2009 r. ${ }^{10}$ Problem ten częściowo został w nowej ustawie rozstrzygnięty, wszak $z$ tego typu ewentualnego normatywnego ograniczenia zastosowania wskazanych definicji legalnych (,w rozumieniu ustawy”) zrezygnowano. Na marginesie - o braku trafności wskazanych poglądów, dopuszczających rożny sposób wykładni pojęcia tajemnicy państwowej oraz tajemnicy służbowej, świadczyć może fakt, że skoro ustawodawca w związku $\mathrm{z}$ wprowadzeniem definicji informacji niejawnych w miejsce dotychczasowych tajemnic zdecydował tym samym, iż konieczna jest harmonizacja terminologiczna $z$ tym związana na gruncie innych aktów prawnych, to wydaje się, że pojęcia te nakazuje interpretować w sposób jednakowy. Faktycznie jednak poruszony problem ma znacznie szerszy zasięg. Bliższa analiza dokonanych zmian nowelizacyjnych prowadzi bowiem do wniosku, że w wysokim stopniu cechuje je pierwiastek przypadkowości. Ma to swoje następstwa w braku konsekwencji terminologicznej szeregu przepisów tych aktów prawnych, które ustawodawca musiał poddać nowelizacji z mocy nowej ustawy o ochronie informacji niejawnych, posługiwały się bowiem usuniętym $z$ porządku prawnego pojęciem tajemnicy państwowej oraz tajemnicy służbowej. Niestety, sposób, w jaki dokonano wskazanych zmian, budzi zastrzeżenia, ponieważ okazuje się on zupełnie niejednolity i nie zawsze koresponduje $z$ przyjętą w nowej ustawie koncepcją ochrony informacji niejawnych. Oczywiście w wielu aktach prawnych wskazuje się, zgodnie $z$ założeniami wynikającymi $z$ nowej ustawy, że ochronie tej podlegają tylko te informacje niejawne, które zaopatrzono w gryf tajności (np. art. $179 \S 1$ i art. $181 \S 1$ k.p.k., art. $265 \S 1$ i art. $266 \S 2$ k.k.). $Z$ drugiej jednak strony szereg poddanych nowelizacji przepisów zapewnia „ochronę informacji niejawnych" (np. art. 30 pkt 1 ustawy z 29 sierpnia 1997 r. o ochronie danych osobowych ${ }^{11}$; art. 226 k.p.k.; art. 248 § 1 k.p.c.). Zatem

10 Zob. uzasadnienie uchwały Sądu Najwyższego z 26 marca 2009 r., I KZP 35/08, OSNKW 2009, nr 5, poz. 33.

11 Dz.U. z 1997 r. Nr 133, poz. 882 i 883 ze zm. 
problem oznaczenia takiej wiadomości gryfem tajności zdaje się pozostawać dla autora nowelizacji bez znaczenia.

Inna przyjęta przez ustawodawcę koncepcja nowelizacyjna zakłada $z$ kolei ochronę „tajemnicy prawnie chronionej”. Argumentacja celowościowa nakazuje przyjąć, że pojęcie takiej tajemnicy obejmuje po noweli informacje niejawne oznaczone właściwą klauzulą. Niemniej jednak takie uproszczenie interpretacyjne może prowadzić do nieoczekiwanych konsekwencji. Dla przykładu, w wypadku wielu przepisów różnych aktów prawnych, które chroniły dotychczas tajemnicę państwową (np. art. 57 ust. 1 ustawy z 30 czerwca 2000 r. Prawo własności przemysłowej ${ }^{12}$ ), wskutek nowelizacji rozszerzono granice tej ochrony na inne kategorie informacji niejawnych.

Wydaje się zatem, że brak jednolitej terminologii ustawowej w zakresie określenia tego typu przedmiotu ochrony prowadzić będzie w praktyce do istotnych wątpliwości interpretacyjnych, związanych m.in. $z$ ustaleniem wzajemnych relacji pomiędzy regulacjami nowej ustawy o ochrony informacji niejawnych (w szczególności art. 1 ust. 1 i art. 5 ustawy) a przepisami wielu aktów prawnych poddanych zarazem nowelizacji. Także w tej płaszczyźnie, pomimo deklaracji ustawodawcy, nowa ustawa wprowadza w istocie większy niż dotychczas bałagan pojęciowy, co niewątpliwie utrudni stosowanie nowych rozwiązań w praktyce i może być źródłem licznych nieprawidłowości ${ }^{13}$. Oczywiście tego typu wnioski nabierają znaczenia również w płaszczyźnie prawnokarnej. Także tutaj brak harmonizacji rozwiązań służących ochronie informacji niejawnych, z jednej strony na gruncie instrumentów prawa administracyjnego, $z$ drugiej natomiast - prawa karnego. Jak bowiem wyżej dowiedziono, przepisy o charakterze administracyjnoprawnym moga zapewniać ochronę informacjom niejawnym albo „tajemnicom prawnie chronionym", niezależnie od faktu nadania im klauzuli tajności, podczas gdy w zakresie przestępstw kodeksowych zaopatrzenie informacji takim gryfem jest koniecznym elementem uru-

12 Dz.U. z 2001 r. Nr 49, poz. 508 ze zm.

13 Zob. M. Leciak, Tajemnica, s. 99-112. 
chomienia ochrony prawnokarnej ze strony przepisów ujętych w art. 265 i art. 266 § 2 k.k.

Wobec powyższych wniosków aktualne mimo wszystko może stać się pytanie o normatywny charakter przyjętych definicji informacji niejawnych. Chodzi mianowicie o ustalenie koniecznych elementów tych definicji, które faktycznie ją współtworzą. Całościowa analiza tego problemu bez wątpienia przekraczałaby ramy tego artykułu. Niemniej jednak warto przypomnieć, że dotychczas rekonstrukcja pojęcia tajemnicy państwowej oraz tajemnicy służbowej wymagała analizy następujących elementów ustawowych:

1) definicji materialnej $z$ art. 2 pkt 1 ustawy $z 1999$ r. (definicja tajemnicy państwowej) lub art. 2 pkt 2 ustawy z 1999 r. (definicja tajemnicy służbowej),

2) elementu formalnego $z$ art. 23 ust. 1 ustawy $z 1999$ r. (w odniesieniu do tajemnicy państwowej) lub art. 23 ust. 2 ustawy z 1999 r. (w odniesieniu do tajemnicy służbowej),

3) w przypadku tajemnicy państwowej także elementu opisowego zawartego w załączniku nr 1 do ustawy z 1999 r. („Wykaz rodzajów informacji, które mogą stanowić tajemnicę państwową").

Kwestią wręcz drugorzędną w tym miejscu pozostaje już natomiast rozstrzygnięcie, które $z$ tych elementów faktycznie współtworzą definicję tajemnicy państwowej oraz tajemnicy służbowej ${ }^{14}$. Tego typu kilkuetapowe ustalanie charakteru klasyfikowanej informacji, krytykowane przez twórcę nowych rozwiązań prawnych, stanowiło jednak, jak się wydaje, walor ustawy z 1999 r. Z tego choćby względu, że niwelowało możliwość pomyłek i znacznej uznaniowości po stronie podmiotów uprawnionych do nadawania informacjom

${ }^{14} \mathrm{~W}$ tym względzie zarysowały się w doktrynie dwa odmienne stanowiska. Pierwsze $z$ nich zakłada wyłącznie materialne rozumienie wskazanych kategorii tajemnic (zob. W. Wróbel, op.cit., s. 132; T. Szewc, Ochrona informacji niejawnych. Komentarz, Warszawa 2007, s. 70; M. Leciak, Tajemnica, s. 79 i n.; P. Burzyński, Tajemnica państwowa jako przedmiot ochrony regulacji prawnokarnej, Czasopismo Prawa Karnego i Nauk Penalnych 2002, nr 1, s. 24). Zgodnie zaś z drugim definicja tajemnicy państwowej oraz tajemnicy służbowej ma mieszany (materialno-formalny) charakter (zob. B. Kunicka-Michalska, op.cit., s. 501; S. Hoc, op.cit., s. 89). 
gryfu tajności, wyznaczając w tym zakresie w miarę precyzyjne i jasne kryteria.

Co się jednak tyczy dokonanej nowelizacji funkcjonujących definicji ustawowych, to trzeba zauważyć, że koncentruje się ona głównie na dwóch aspektach:

1) rezygnacji $z$ wykazu informacji niejawnych, które mogą być oznaczone klauzulą „ściśle tajne” lub „tajne”, czyli realizujących kryteria definicji materialnej tajemnicy państwowej (załącznik nr 1 do ustawy z 1999 r.),

2) scaleniu w art. 5 nowej ustawy dotychczas funkcjonujących definicji informacji niejawnych o charakterze materialno-warunkowym (art. 2 pkt 1 i 2 ustawy z 1999 r.) wraz z elementem formalnym tych definicji (zamieszczonym w art. 23 ustawy z 1999 r.).

Może zatem zastanawiać, czy przyjęcie ad hoc związanego $\mathrm{z}$ nową ustawą założenia, że nowe definicje informacji niejawnych (art. 5 ustawy) mają charakter formalny, będzie zupełnie prawidłowe. Bliższa analiza przyjętej koncepcji prowadzi wszak do wniosku, że spór o normatywny charakter tych definicji nie został w drodze noweli rozstrzygnięty. Świadczyć może o tym m.in. fakt, że ustawodawca $\mathrm{w}$ zakresie materialnej definicji $\mathrm{z}$ art. 1 ust. 1 ustawy uznał za informację niejawną już taką informację, która gryfu tajności nie ma. Mogłoby to sugerować, że nadanie klauzuli ma jednak przede wszystkim znaczenie dla czysto „biurowej” ochrony informacji ${ }^{15}$. Dodatkowo także analiza innych przyjętych rozwiązań prawnych związanych $z$ próbą zachowania konsekwencji terminologicznej w krajowym porządku normatywnym, polegającą na wprowadzeniu nowych pojęć informacji niejawnych również do innych aktów prawnych dysponujących dotychczas terminem „tajemnica państwowa” lub „tajemnica służbowa”, prowadzić może do wniosku o niekoniecznie czysto formalnym rozumieniu pojęcia „informacja niejawna”. Jak bowiem wcześniej wspomniano, w szeregu znowelizowanych w ten sposób aktach normatywnych ustawodawca wprowadził mechanizmy ochrony informacji niejawnych albo „tajemnicy prawnie chronionej” niezależnie od faktu zaopa-

15 Zob. M. Leciak, Tajemnica, s. 92. 
trzenia ich w gryf tajności. Problem ten wymaga głębszej analizy, na którą nie ma, niestety, miejsca w tym opracowaniu.

Krytyczna ocena analizowanych definicji normatywnych informacji niejawnych, związana głównie $z$ ich nieprecyzyjnym ujęciem, nakazuje również, choćby częściowo odnieść się do problemu zgodności wprowadzonych rozwiązań z regulacjami Konstytucji. Kwestia ta budziła zastrzeżenia także na gruncie ustawy z 1999 r. ${ }^{16}$ Analiza pod tym kątem wszystkich elementów ustawowych współtworzących wskazane definicje przekracza ramy tego opracowania. Niemniej jednak trzeba krótko tylko zasygnalizować, że zakres dóbr wyliczonych w art. 5 ust. 1, 2, 3 i 4 ustawy, których ochrona uzasadnia utajnienie informacji, sprawia wrażenie szerszego niż w art. 2 pkt. 1 i 2 ustawy z 1999 r. Tym samym ustawodawca zwykły zdaje się istotnie wykraczać poza konstytucyjne klauzule limitacyjne $z$ art. 31 ust. 3 i art. 61 ust. 3 Konstytucji, które wyznaczają zakres możliwych ograniczeń w zakresie obywatelskiego prawa dostępu do informacji ${ }^{17}$.

\section{Prawnokarne aspekty zmiany modelu ochrony informacji niejawnych}

Powyżej opisane modyfikacje w zakresie sposobu ochrony informacji niejawnych wywołują istotny wpływ na interpretację normatywnych znamion przestępstw $z$ art. $265 \S 1$ k.k. i art. $266 \S 2$ k.k. Jak bowiem wcześniej wskazano, przekształcenie przepisów k.k., polegające na zastąpieniu tajemnicy państwowej oraz tajemnicy służbowej informacją niejawną o określonej klauzuli, nie jest jedyną zmianą materii prawnokarnej w tym zakresie. Wydaje się zresztą, że przy dokonywaniu zarówno modyfikacji kodeksowych, jak i zmian w obrębie nowej ustawy o ochronie informacji niejawnych

16 Zob. P. Szkudlarek, Ustawa o ochronie informacji niejawnych a prawa obywateli, Państwo i Prawo 2000, nr 7, s. 62; T. Szewc, op.cit., s. 71-72.

17 Zob. M. Leciak, Definicja legalna tajemnicy państwowej oraz tajemnicy służbowej $w$ świetle przepisów Konstytucji RP, Studia Iuridica Toruniensia 2009, nr 5, s. 86. 
ustawodawca nie był świadomy ich rzeczywistych konsekwencji w płaszczyźnie interpretacyjnej, a zarazem także praktycznej.

Niezależnie od sposobu rekonstrukcji definicji ustawowych pojęcia „informacja niejawna”, prawnokarną ochronę takiej informacji ustawodawca uzależnia już wyraźnie od faktu nadania jej właściwej klauzuli tajności. Twierdzenie to odnosi się do przestępstw stypizowanych zarówno w art. 265 k.k., jak i art. 266 § 2 k.k. Następstwa przyjętego rozwiązania są daleko idące i faktycznie prowadzić będą do ograniczenia możliwości ścigania sprawców zachowań skierowanych przeciwko poufności informacji niejawnych. Co więcej, także $z$ punktu widzenia konstytucyjnych praw i wolności jednostki budzić mogą istotne zastrzeżenia.

Na początek wypada zauważyć, że w drodze takiego ukształtowania znamion ustawowych art. $265 \S 1$ k.k. i art. $266 \S 2$ k.k. doprowadzono do sytuacji, w której byt wspomnianych przestępstw uzależniony został w niezwykle wysokim stopniu od uznania urzędnika. Nadawanie, znoszenie, zawyżanie lub zaniżanie klauzul tajności stało się wszak czynnością mogącą istotnie wpływać na treść zakazu karnego. Rozwiązanie takie można by pewnie zaakceptować, jednakże przy założeniu jednoczesnego spełnienia co najmniej dwóch warunków. Po pierwsze precyzyjne i jasne ukształtowanie definicji informacji niejawnych oraz wyraźne określenie kryteriów nadawania im gryfu tajności przez urzędnika. Jak wcześniej argumentowano, postulat tego rodzaju nie został przez ustawodawcę w sposób zadowalający zrealizowany, ponieważ nieostre i wysoce ocenne ustawowe struktury pojęciowe rodzą realną możliwość nadinterpretacji. Po drugie $z$ kolei konieczne wydaje się także funkcjonowanie odpowiednich mechanizmów normatywnych zapewniających odpowiedzialność urzędnika uprawnionego do klasyfikowania informacji za różnego rodzaju zachowania mające charakter nadużyć w tym zakresie. Nie ma co ukrywać, że pożądanym środkiem zabezpieczającym i zarazem kontrolnym powstrzymującym od bezprawnego nadawania, znoszenia, zawyżania lub zaniżania klauzul tajności powinien być przepis prawnokarny. Dotychczas, w związku ujęciem znamion art. $265 \S 1$ k.k. i art. $266 \S 2$ k.k., taka możliwość co do zasady istniała ${ }^{18}$.

18 Zob. M. Leciak, Tajemnica, s. 86 i n. 
Tymczasem przyjęta przez ustawodawcę koncepcja ochrony informacji niejawnych prowadzi do znacznej szczątkowości regulacji przewidujących odpowiedzialność karną urzędnika za takie zachowania. Innymi słowy, nie gwarantuje ona wystarczających środków ochrony $\mathrm{w}$ tym zakresie, zezwalając $\mathrm{w}$ zasadzie na realne $\mathrm{w}$ praktyce nadużycia w zakresie ochrony informacji niejawnych, a tym samym na możliwe, czasami daleko idące, ograniczanie konstytucyjnych uprawnień obywatela w sferze dostępu do informacji. Przyjęte bowiem założenie, że przestępstwem $z$ art. 265 k.k. lub art. $266 \S 2$ k.k. jest ujawnienie wyłącznie takiej informacji, którą opatrzono jedną z klauzul tajności, prowadzi do wniosku, iż nie dojdzie do realizacji znamion tych przestępstw w sytuacji, w której urzędnik doprowadza do ujawnienia poufnej informacji niezaopatrzonej w taki gryf, np. gdy bezprawnie odmawia jego nadania, bezprawnie go znosi albo też zaniża go w taki sposób. W nowym porządku normatywnym ujawnienie jako przestępstwo dotyczyć ma wszak informacji oznaczonej odpowiednią klauzulą, niezależnie od tego, czy nadaną w sposób prawidłowy. Nie jest to jedyne następstwo nowych rozwiązań normatywnych, które $z$ jednej strony istotnie zwiększają woluntaryzm urzędników, $z$ drugiej zaś mogą tym samym negatywnie kształtować możliwość realizacji uprawnień konstytucyjnych jednostki. Zresztą także określony interes państwa może zostać poważnie zagrożony w drodze tego typu zachowań. Dla przykładu można wskazać na przypadek, w którym dochodzi do bezprawnej odmowy przyznania właściwej klauzuli informacjom, które $z$ takiej ochrony winny korzystać. Oczywiście również w tej sytuacji nie może być mowy o realizacji znamion art. $265 \S 1$ k.k. lub art. 266 § 2 k.k. Można co najwyżej zastanawiać się nad kwalifikacją prawnokarną z art. 231 k.k., aczkolwiek jedynie przy założeniu realizacji kryterium podmiotowego co do znamienia „funkcjonariusz publiczny”. Zbliżone problemy dotyczyć mogą także przypadków nadawania klauzuli tajności informacjom, które z takiej ochrony nie powinny korzystać, bądź też zawyżania nadanej klauzuli. W tego typu sytuacjach sprawca ujawniający takie informacje mógłby odpowiadać karnie nawet za przekazanie informacji nieistotnych $z$ punktu widzenia interesów państwa. Zarzut naruszenia zasady określoności przestępstwa (nullum crimen sine lege) 
może więc w opisanych przypadkach okazać się zupełnie uzasadniony $z$ uwagi na niejasne przesłanki odpowiedzialności karnej $z$ art. 265 k.k. i art. $266 \S 2$ k.k.

Wobec powyższego przyjęta koncepcja ochrony informacji niejawnych może prowadzić do faktycznego stanowienia prawa przy niejasno określonych kryteriach tego procesu, gdzie swoboda uznania urzędnika jest równoznaczna $z$ kształtowaniem in concreto treści zakazu karnego. Całkowicie niezrozumiale brzmi w świetle powyższego przywołane wcześniej twierdzenie $z$ uzasadnienia projektu ustawy, że nowa ustawa zwiększa jawność życia publicznego i ułatwia dostęp do informacji publicznej, a tym samym poszerza sferę wolności i praw jednostek w zakresie dostępu do informacji ${ }^{19}$. Podsumowując, $z$ jednej strony błędna decyzja urzędnika może skutkować odpowiedzialnością karną obywatela za czyn z art. 265 k.k. lub art. $266 \S 2$ k.k., z drugiej z kolei zawiniony brak klauzuli nie będzie generować konsekwencji prawnokarnych. Przyjęte więc $\mathrm{w}$ nowej ustawie rozumienie informacji niejawnej prowadzi do luki i niekonsekwencji w zakresie jej prawnokarnej ochrony. Wydaje się więc, że stanowi raczej niezamierzony przez ustawodawcę krok wstecz w relacji $z$ dotychczasowymi rozwiązaniami normatywnymi.

Sposób nowelizacji przepisów k.k. rodzi zresztą wiele innych wątpliwości. Identyfikowanie bytu przestępstw z art. 265 k.k. i art. $266 \S 2$ k.k. $z$ nadaną klauzulą tajności nasuwa zastrzeżenia z punktu widzenia nieadekwatności takiego założenia względem informacji przekazywanych ustnie. Wiąże się z tym ponadto argument odwołujący się do potrzeby prawnokarnej ochrony także tych informacji, które znajdując się w fazie ich opracowywania, nie zostały jeszcze zaopatrzone we właściwy gryf tajności. O ile w art. 1 ust. 1 nowej ustawy wskazuje się, że jej przepisy zapewniają ochronę informacji niejawnych także w fazie ich opracowywania oraz niezależnie od formy i sposobu ich wyrażania, o tyle rodzi się od razu wątpliwość, o jaką ochronę chodzi ustawodawcy, skoro opowiadając się za formalnym rozumieniem pojęcia informacji niejawnej stwierdza dalej, że jest nią dopiero taka wiadomość, której nadano klauzulę tajności. Wobec tego w razie ujawnienia

19 Zob. Uzasadnienie, s. 23. 
informacji, której urzędnik nie zdołał jeszcze nadać gryfu tajności, nie może być mowy o dokonaniu jednego $z$ przestępstw $z$ art. 265 k.k. lub art. $266 \S 2$ k.k.

Poza tym, w związku $z$ rezygnacją $z$ podziału informacji na tajemnicę państwową oraz tajemnicę służbową i wprowadzeniem w ich miejsce wyłącznie informacji niejawnej, może też zastanawiać potrzeba funkcjonowania odmiennych $z$ punktu widzenia konstrukcji znamion ustawowych przestępstw, tzn. ujawnienia tajemnicy państwowej $z$ art. 265 § 1, 2 i 3 k.k. (czyli wedle nowej ustawy informacji niejawnych o klauzuli „ściśle tajne” lub „tajne”) oraz ujawnienia tajemnicy służbowej z art. $266 \S 2$ k.k. (czyli informacji o klauzuli „poufne” lub „zastrzeżone”). Różnice w ich normatywnej strukturze są bowiem dostrzegalne i dotyczą m.in. zakresu podmiotowego oraz znamion strony przedmiotowej. Może się natomiast zdarzyć, że dla przykładu informacje, które na gruncie ustawy z 1999 r. mogłyby zostać uznane za tajemnicę państwową, w nowej ustawie mogłyby równie dobrze zostać zaklasyfikowane jako informacja o gryfie „poufne” lub „zastrzeżone, a zatem, mówiąc wprost, ich ujawnienie mogłoby już stanowić czyn z art. $266 \S 2$ k.k. Wydaje się więc, że ustawodawca nie jest do końca świadomy konsekwencji, które wiążą się z próbą zastąpienia wzmiankowanych definicji legalnych zbiorczym pojęciem ,informacja niejawna”. Jak wynika z powyższego, dotyczy to również materii prawnokarnej.

W doktrynie prawa karnego istotnym problemem interpretacyjnym jest także kwestia charakteru podmiotowego omawianych przestępstw. O ile w odniesieniu do art. $266 \S 2$ k.k. nie powinna ona budzić wątpliwości, o tyle ustalenie, czy pod względem podmiotowym zachowania ujęte w art. $265 \S 1$ i 2 k.k. stanowią przestępstwa powszechne czy indywidualne, jest już bardziej złożone. Problem ten pozostaje sporny $\mathrm{w}$ literaturze ${ }^{20}$. Stanowisko $\mathrm{w}$ tej

20 Stanowisko wskazujące na powszechny charakter tych przestępstw zajmują m.in.: B. Kunicka-Michalska, op.cit., s. 489; P. Burzyński, op.cit., s. 26 i n.; A. Marek, op.cit., s. 478; J. Piórkowska-Flieger, op.cit., s. 545; J. Wojciechowski, Kodeks karny. Komentarz. Orzecznictwo, Warszawa 1998, s. 464. Indywidualny typ przestępstw z art. 265 § 1 i 2 k.k. postulują natomiast: W. Wróbel, op.cit., s. 134; M. Leciak, Tajemnica, s. 131 i n.; 
sprawie zajął również Sąd Najwyższy w uchwale z 26 marca 2009 r. $^{21}$, opowiadając się za szerokim rozumieniem obowiązku poufności. Orzeczenie to zostało jednak poddane istotnej krytyce ${ }^{22}$. Przeprowadzone modyfikacje nie rozstrzygają, niestety, tych wątpliwości, ponieważ w zasadzie nie prowadzą do większych zmian co do interpretacji tego problemu. Nie sposób ich z pewnością dostrzec bezpośrednio w obrębie konstrukcji kodeksowych. Co innego można natomiast powiedzieć, jeżeli chodzi o określenie adresatów nowej ustawy o ochronie informacji niejawnych. Ustalenia w tym zakresie mogą zaś kształtować sposób wykładni co do podmiotu wskazanych przestępstw kodeksowych ${ }^{23}$. W ujęciu art. 1 ust. 2, przepisy nowej ustawy mają zastosowanie do:

1) organów władzy publicznej, w szczególności:

a) Sejmu i Senatu,

b) Prezydenta Rzeczypospolitej Polskiej,

c) organów administracji rządowej,

d) organów jednostek samorządu terytorialnego, a także innych podległych im jednostek organizacyjnych lub przez nie nadzorowanych,

e) sądów i trybunałów,

f) organów kontroli państwowej i ochrony prawa;

2) jednostek organizacyjnych podległych ministrowi obrony narodowej lub przez niego nadzorowanych;

3) Narodowego Banku Polskiego;

4) państwowych osób prawnych i innych niż wymienione w pkt. 1-3 państwowych jednostek organizacyjnych;

E. Czarny-Drożdżejko, Dziennikarskie dochodzenie prawdy a przestępstwo zniesławienia $w$ środkach masowego komunikowania, Prace Instytutu Własności Intelektualnej UJ, z. 90, Kraków 2005, s. 344.

${ }^{21}$ Uchwała Sądu Najwyższego 26 marca 2009 r., I KZP 35/08, OSNKW 2009, nr 5, poz. 33.

${ }^{22}$ Zob. glosy do uchwały Sądu Najwyższego z 26 marca 2009 r.: M. Leciaka, Prokuratura i Prawo 2009, nr 9 (krytyczna); J. Skrzydło, Państwo i Prawo 2010, nr 6 (krytyczna); K. Tkaczyk, Palestra 2010, nr 5-6 (krytyczna); J. Raglewskiego, LEX/el 2009 (krytyczna); S. Hoca, Prokuratura i Prawo 2010, nr 3 (aprobująca).

${ }^{23}$ Zob. W. Wróbel, op.cit., s. 135; M. Leciak, Tajemnica, s. 140 i n. 
5) jednostek organizacyjnych podległych organom władzy publicznej lub nadzorowanych przez te organy;

6) przedsiębiorców zamierzających ubiegać się albo ubiegających się o zawarcie umów związanych $z$ dostępem do informacji niejawnych lub wykonujących takie umowy albo wykonujących na podstawie przepisów prawa zadania związane $z$ dostępem do informacji niejawnych.

Dokonana przez ustawodawcę zmiana polega na rozszerzeniu tego katalogu o podmioty określone w art. 1 ust. 2 pkt 5 (jednostki organizacyjne podległe organom władzy publicznej lub nadzorowane przez te organy). Nie wywołuje ona wprawdzie większego wpływu na interpretację znamion ustawowych wspomnianych kategorii przestępstw, niemniej jednak należy zauważyć, że dokonując wraz $\mathrm{z}$ uchwaleniem nowej ustawy jednoczesnej nowelizacji art. $265 \S 1$ i art. $266 \S 2$ k.k., ustawodawca potwierdził istnienie swoistej zależności terminologicznej w zakresie rozumienia pojęcia informacji niejawnych na gruncie ustawy o ochronie informacji niejawnych oraz wskazanych przepisów kodeksowych. Zależność ta była dotychczas negowana przez tę część doktryny, która powszechny charakter przestępstw $z$ art. $265 \S 1$ i 2 k.k. argumentowała odmiennym rozumieniem tych pojęć. Stanowisko to zaaprobował zresztą Sąd Najwyższy we wspomnianej uchwale z 26 marca 2009 r. Dokonana nowelizacja może natomiast potwierdzać potrzebę sięgnięcia do przepisów ustawy o ochronie informacji niejawnych w zakresie rekonstrukcji normy sankcjonowanej z art. 265 § 1 i 2 k.k., a tym samym także do przepisów określających katalog podmiotów zobowiązanych do ochrony informacji niejawnych (art. 1 ust. 2), który ma charakter ograniczony.

Problemem wartym zasygnalizowania, nie tylko zresztą ze względu na implikacje prawnokarne, jest ponadto kwestia zasadniczej zmiany modelu temporalnej ochrony informacji niejawnych. Wspomnieć tylko warto, że dotychczas ustawa z 1999 r. wyznaczała konkretne okresy ochrony informacji niejawnych oznaczonych jako tajemnica państwowa lub tajemnica służbowa (art. 25 ustawy), z możliwością ich skracania lub przedłużania. Tymczasem przyjęte w nowej ustawie rozwiązanie zakłada, że informacje niejawne podlegają ochronie do czasu zniesienia lub zmiany klauzuli tajności. 
Kierownicy jednostek organizacyjnych zostali przy tym zobowiązani do dokonywania nie rzadziej niż raz na 5 lat przeglądu materiałów w celu ustalenia, czy spełniają one ustawowe przesłanki ochrony (art. 6 ustawy). $Z$ jednej strony wydaje się, że nowe rozwiązanie może skuteczniej zapobiec dotychczasowym sytuacjom, w których informacja pozostawała tajna $z$ uwagi na ustawowy okres jej ochrony, pomimo że jej potencjalne ujawnienie nie zagrażało już podstawowym interesom państwa. $Z$ drugiej jednak strony przyznana urzędnikom przez ustawodawcę, a zarazem w sporym zakresie wolna od mechanizmów kontrolnych znaczna uznaniowość w sferze klasyfikowania informacji, przy nieprecyzyjnych kryteriach ustawowych oceny charakteru takiej informacji, może prowadzić do podobnych nieprawidłowości w praktyce. Jeśli chodzi o płaszczyznę prawnokarną, wydaje się poza tym, że z punktu widzenia interesów zwykłego obywatela sytuacja, w której informacje niejawne podlegały ochronie przez ściśle wyznaczony okres, co pozwalało zorientować się, czy ich ujawnienie jest jeszcze objęte dyspozycją zakazu karnego, była znacznie korzystniejsza niż obecna, w której faktycznie $z$ dnia na dzień charakter informacji może ulec definitywnej zmianie, np. w drodze zawyżenia nadanej jej klauzuli lub jej zniesienia.

Poza tym w nowej ustawie przyjęto jeszcze inne założenie dotyczące potrzeby weryfikacji nadanych klauzul. W ujęciu art. 181 ust. 1 ustawy „Kierownicy jednostek organizacyjnych przeprowadzą, w terminie 36 miesięcy od dnia wejścia w życie ustawy, przegląd wytworzonych w podległych im jednostkach organizacyjnych materiałów zawierających informacje niejawne w celu ustalenia, czy spełniają ustawowe przesłanki ochrony na podstawie ustawy, i dokonają w razie potrzeby zmiany lub zniesienia klauzuli tajności”. Nie ma co ukrywać, że z uwagi na konieczność analizy tysięcy dokumentów, w jak się wydaje dość krótkim terminie, czynność ta może okazać się działaniem mechanicznym, co rzecz jasna może negatywnie wpłynąć na jej jakość. Należy przy tym natomiast pamiętać, że dowolność uznania urzędnika nie jest po nowelizacji w każdym przypadku ograniczona sankcją karną za ewentualne nadużycia w tym zakresie. Na marginesie, wydaje się też, iż wskazany obowiązek może stać się istotnym obciążeniem dla urzędników 
i tym samym częściowo paraliżować możliwość dokonywania aktualnych czynności służbowych.

\section{Podsumowanie}

Przedstawione wyżej zmiany legislacyjne zasługują bez wątpienia na krytyczną ocenę. Stwierdzenie to odnosi się zarówno do analizowanych przepisów nowej ustawy o ochronie informacji niejawnych, jak i do zmian w obrębie konstrukcji normatywnych k.k. Jak zresztą wskazano, negatywna ocena płaszczyzny prawnokarnej jest następstwem zmian w obrębie charakteru informacji niejawnych w nowej ustawie, które istotnie wpłynęły na sposób wykładni znamion strony przedmiotowej wzmiankowanych przestępstw. Wydaje się zatem w świetle zaprezentowanej wcześniej argumentacji, że zmiana modelu ochrony informacji niejawnych, w tym rezygnacja z podziału informacji niejawnych na tajemnicę państwową oraz tajemnicę służbową, nie ma racjonalnego wsparcia w krajowym porządku normatywnym. Na pewno nie znajdziemy tego typu argumentacji w uzasadnieniu projektu ustawy. Podane w art. 5 ustawy definicje legalne nie wyjaśniają w sposób wystarczająco precyzyjny kryteriów nadawania określonych klauzul tajności. Pamiętając o tym, że klauzulę taką nadaje jednoosobowo urzędnik, dowolność interpretacyjna po jego stronie skutkować może istotnymi nadużyciami w tym zakresie, choćby w postaci zawyżania lub zaniżania gryfu tajności ${ }^{24}$. Problem ten jest oczywiście najbardziej istotny w odniesieniu do informacji oznaczanych najwyższymi klauzulami. Niekorzystne następstwa takiego rozwiązania są widoczne zarówno w płaszczyźnie ochrony uprawnień jednostki w sferze dostępu do informacji, jak i interesów samego państwa. Wydaje się również, że wobec tak niejasnych przesłanek nadawania tego typu klauzul rezygnacja $z$ istniejącego dotychczas wykazu informacji, którym można nadać klauzulę „ściśle tajne” lub „tajne” (załącznik nr 1 do

24 Zob. Uwagi Stowarzyszenia ds. bezpieczeństwa systemów informacyjnych do projektu ustawy o ochronie informacji niejawnych, Warszawa 21.08.2009 r., s. 3. 
ustawy z 1999 r.), była jednak decyzją zbyt pochopną. Nie sposób odnaleźć zresztą w uzasadnieniu racji, które tłumaczyłyby tego rodzaju zabieg legislacyjny. Ustawodawca argumentuje wszak jedynie, iż rezygnacja $z$ wykazów wiąże się $z$ tym, że były one w praktyce lekceważone i zbyt szerokie. $Z$ punktu widzenia pożądanej zwiększonej jawności życia publicznego kierunek obrany przez ustawodawcę jest jednak $z$ pewnością odwrotny. Wykaz ten był bowiem weryfikatorem materialnych cech badanej informacji, co z jednej strony ułatwiało właściwy dobór klauzuli, $z$ drugiej natomiast pozwalało na weryfikację prawidłowości nadanego już gryfư ${ }^{25}$. Pożądane ograniczenie uznaniowości urzędników w sferze klasyfikowania informacji okazuje się więc w świetle nowo przyjętych założeń trudne do faktycznej realizacji. Poza tym zakładane przez ustawodawcę uelastycznienie mechanizmów ochrony informacji niejawnych, jakkolwiek dostrzegalne, prowadzić będzie jednak nie tylko do rzeczywistego ich skomplikowania, ale także do istotnego upośledzenia instrumentów kontrolnych w zakresie klasyfikowania poufnych informacji. Tym samym również postulat większej jawności życia publicznego i dostępu do informacji okazuje się nieprawdziwy, a wręcz rodzi konstatację, że nowa ustawa uprawnienia te może jeszcze bardziej ograniczać. Ma to oczywiście również swoje następstwa w płaszczyźnie prawnokarnej, wszak utożsamianie informacji niejawnych z gryfem tajności niepotrzebnie komplikuje wystarczająco już zawiłe $z$ interpretacyjnego punktu widzenia zagadnienia związane $z$ prawnokarną oceną zachowań w postaci ujawnienia poufnych informacji.

25 Zob. Uwagi Agencji Wywiadu do projektu ustawy o ochronie informacji niejawnych, Warszawa 7.08.2009 r., s. 1. 


\section{SUMMARY}

\section{Criminal law aspects of the new Law on Protection of Classified Information}

The new law on protection of classified information removed from the Polish legislation the definition of state secrets and official secrets. In their place, introduced the concept of classified information, where the level of protection depends on the classification given to them. This type of legal definitions are defined as evaluative and vague, which can lead to numerous irregularities. The more that the new law does not provide the appropriate mechanisms of control. The consequence of the accepted model of the protection of classified information is a dependency of making a crime defined under Articles 265 and 266 of the Criminal Code from the fact whether the disclosed information had a confidentiality clause.

Keywords: amendment to an act, disclosure of information, classified information, state secret, official secret, confidentiality clause, criminal liability 